\title{
Global Souls and Youth Moves
}

\section{Vinita Srivastava}

Ryerson University

\section{digital.library.ryerson.ca/object/393}

Please Cite:

Srivastava, V. (2008) Global Souls and Youth Moves. [Review of the book Youth Moves, an anthology by N. Dolby \& F. Rizvi]. Academic Matters.

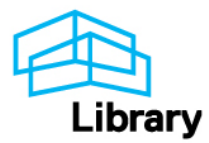




\section{Print Magazin

\section{GURRENT ISSUE:}

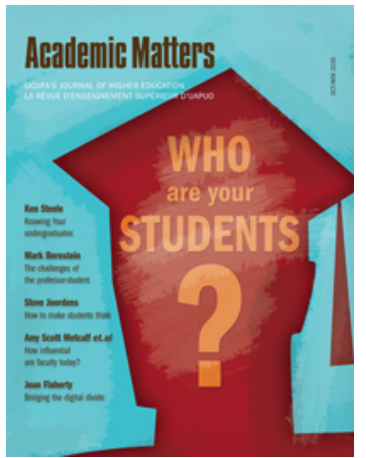

Who are your students?

October-November 2010

What motivates today's

undergraduates and mature students? How can you make students think critically? Do faculty still have influence in the university? How have they embraced new technology? Can we still afford the teacher/researcher model in the academy?

\section{BONTENI}

Knowing Your Undergraduates Ken Steele

With career-oriented students seeking variety in their university experiences, universities are diversifying their appeal. The downsides are often talked about, but this evolution could well help universities in regions of population decline survive, while offering students clearer choices among a broader range of educational options. MORE>

Back to school days

Mark Bernstein

The challenges and joys of the professor-student. At age 51, a neurosurgeon returns to school. MORE>

You Can Lead Students To Knowledge, But How Do You Make Them Think?

Steve Joordens

The psychological defences students have get in the way of learning critical thought. How can university teachers encourage student to confront these defences? MORE>

How influential are faculty today? Responses from the Canadian

\section{FEATURES 11/21/2010}
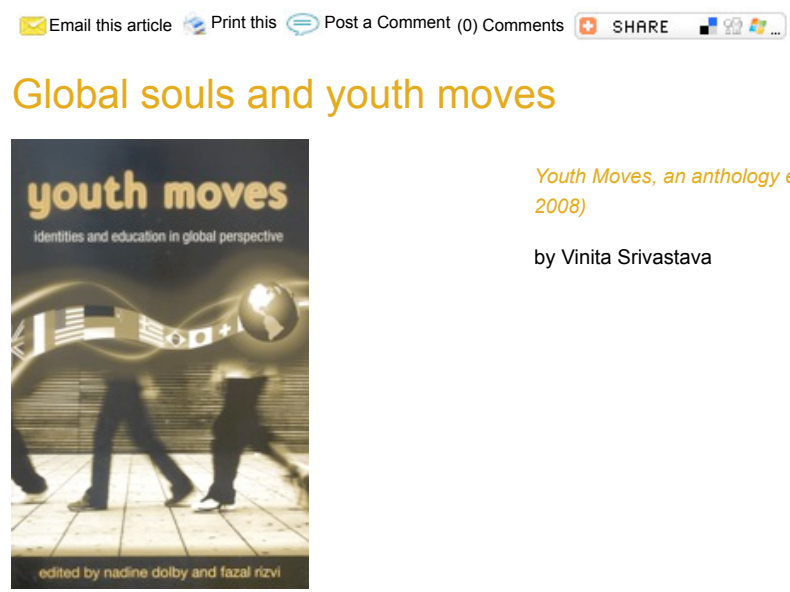

Youth Moves, an anthology edited by Nadine Dolby and Fazal Rizvi (Routledge, 2008)

by Vinita Srivastava

Youth Moves, a new collection of critical essays, seeks to create a sketch of today's global youth. To begin, editors Nadine Dolby and Fazal Rizvi tell a story about a young woman criss-crossing the globe from the U.S. to South Africa and back to the U.S. to visit relatives. With this image of the "global soul" in mind, Dolby and Rizvi open the conversation into different types of youth movements: both physical and figurative within the milieu of the ever-increasing pace of commodity, culture, and idea generation of today's networked world.

The global soul, as described by author Pico lyer, is one who knows their way around the transit lounges of Heathrow, O'Hare, and Hong Kong but gets lost in the local streets of their city. Though the editors agree that "most of the world has no idea what the inside of an international airport looks like," they believe that youth identities are "now inextricably linked to the currents of modernity that flow across the world at the speed of a mouse click."

As the director of a multimedia project for marginalized youth, I picked up Youth Moves aiming to understand how international youth connections grow more possible with a "mouse click," as the editors suggest. Are youth using the rapid developments in technology with applications such as Facebook, MySpace, YouTube, and cell phones to engage each other globally and to potentially motivate or activate a new global citizenry? Essays in this collection point to this possibility with examples of youths' constructing intersecting identities within the transnational media-scape.

The aspirations, nihilisms, and realities of these youth presage things to come. As Dolby and Rizvi write, "[youth] movements produce the terrain of the future." I also believe new technologies have enormous capabilities to connect and activate youth. Their online identities, sites, and movements have the potential to create new connections and openings for young global citizens.

The possibilities of these quick-to-form futures grab the attention of the contributors in the collection, who urge their readers to take the movements of youth seriously as they forge the "identities of generations yet to come."

This summer I traveled to Rwanda to meet the leaders of the next generation in East Africa. One third of Rwanda's population is under 35. My opportunity came via a teaching position through Carleton University's Rwanda Initiative, a partnership with the National University of Rwanda (NUR). I went with stacks of magazines, newspaper articles, lesson plans, trepidation, and high hopes. I was warned by the director of the program that multimedia, though the future of news production, would be difficult at NUR owingto funding and infrastructure. Also, government censorship is an issue when producing news online. In Rwanda, the simple "click of a mouse" is complicated. 
professoriate

Amy Scott Metcalfe, Donald Fisher

Yves Gingras, Glen A. Jones, Kjell

Rubenson, and lain Snee

How are the pressure to publish or

perish, fiscal austerity, and the

growing ascendancy of managers

combining to affect the influence of

faculty on academic life? MORE>

Bridging the Digital Divide

Joan Flaherty

A Non-Technical Approach to the Use

of New Technology in Post-Secondary

Teaching and Learning MORE>

Is the teacher-researcher faculty model just too expensive?

Ken Snowdon

The authors of Academic

Transformation argue the current

faculty model of teaching-research is

too costly, short-changes students of

variety, and relies excessively on

part-time faculty. Does their case

stand up to scrutiny? MORE>

Humour Matters

Steve Penfold

Plagiarism: How about a Canada

Research Chair in

Surveillance? MORE>

Editorial Matters

Mark Rosenfeld

Understanding university

students MORE>
The night before my first class on reporting and journalism, I sketched out a lesson plan that spoke about media's powerful potential to help bring about positive changes to society. The lesson involved a photograph taken by Sam Nzima during the 1976 Soweto youth riots. The photo, depicting Hector Pieterson, a young boy who had been shot during the legendary anti-apartheid protests, helped push news of South Africa's apartheid government around the world.

But as I worked on my short talk I grew concerned about two things. First, were the events of 1976 too long ago for the students to connect with? And second, was Rwanda the kind of place where I could bring up issues of power and resistance? A recent report by the Committee to Protect Journalists described a journalist in Kigali who had been beaten for publishing independent news. Was my classroom the right place for me to be saying, "Speak out now. Write now?"

Once my students began writing and handing in assignments, I noticed the biggest difference between the output of first-year university students in Butare, Rwanda, and that of students in Toronto, Canada. Submissions from Butare students were in pencil, on paper torn out of notebooks. In Toronto, submissions were electronic or on white paper printed from the classroom computer. With 75 students and 11 working computers (only about seven can get online), my Rwandan students did not regularly access international or local online hotspots like Facebook at the "click of a mouse."

Internet connections in Rwanda and Ethiopia are among the slowest in the world. The assignment one afternoon: Go online and find a news article. My student's eyes grew wide. Go online! That creates a problem. In Rwanda, radio is still the number one form of communication. How and when might youth stories be shared internationally? How do youth move in Rwanda?

Questions like these about the nature of youth in different societies made me eager to open Youth Moves: Identities and Education in Global Perspective. As a cultural critic, I hoped to learn more about youth and mediascapes and explore the differences in the way youth consume and create identities, movements, and goods in a global context. As a practitioner, I looked for guidance.

The essays in this collection point to some similarities across borders. Though the editors frame their collection optimistically, the majority of the essays point to connections between youth consumption and identity formation within the context of transnational advertising. If not read finely, the book can feel like a simple warning: Youth today, no matter where in the globe they reside, soak themselves in consumer culture. And "consumer-media culture seldom offers young people the pleasures of reflexive knowing or a sense of agency derived from recognizing how their meanings, identities, and affective investments and communities are produced, " in the words of Jane Kenway and Elizabeth Bullen in the article "The Global Corporate Curriculum and the Young Cyberflanêur as Global Citizen."

In Youth Moves, a few essays stand out as the authors search for ways to analyse and contextualize youth consumption. As commodification intensifies, these authors ask, how youth self-reflect, subvert, and stylize their identities in both earnest and playful ways

In their article, Kenway and Bullen argue that young Internet surfers use information and communication technologies (ICTs) as tools for inquiry, providing a "model for the young global citizen." According to these authors, the Internet allows youth to make connections between the products they consume and those who produce them; that is, it allows them to explore aspects of the "cultural and economic aspects of the global cultural economy." The authors acknowledge there are those with no access to ICTs and focus is on those who do. This article gives concrete examples of youth beginning to make these connections online. It is a hopeful text that allots agency to youth with access to ICTs.

"African Canadian Youth and Identity Formation," by Jennifer Kelly, explores identity formation of AfricanCanadian youth and examines how U.S. cultures and the movement of black youth culture affects the transnational identity of these young Canadians. Kelly uses the voices of eight teens. There is a welcome dialogue - and the only occasion in this collection to hear authentic young voices. Kelly connects AfricanCanadian youth identity to a transnational media-scape of black youth emanating from the U.S. However, Kelly's analysis focuses on the youth as audience and not as cultural producers themselves. I am interested in how the youth she interviewed resist or do not resist the cultural products they consume.

Like Rwanda, India is a "young" nation; 54 percent of India's population is under 25, which makes a discussion of the future of youth crucial. In the "Children of Liberalization," Ritty Lukose astutely discusses the next generation in India (dubbed "zippies" in the press). Her piece provides some clarity. The essay outlines both the feminist and the cultural studies theories that can be drawn upon when analyzing "youth, agency, and globalization in post colonial contexts." She writes, "The central organizing framework for youth cultural studies is the identification and tracking of agency and resistance among young people." The underlying hopeful premise of Lukose's paper is that she highlights youth as agents and not as victims of capitalist hegemony. 
One of my favourite essays in the collection is by Sara Nuttall. Her "Youth Cultures of Consumption in Johannesburg," explores "Y Culture," an emergent youth culture in Johannesburg. She explains that $Y$ Culture youth, like the Canadian youth Kelly speaks of, draw on "black American style formations." Here they are described as "explicitly local reworking[s] of the American sign." What is required to examine this "innovative culture," according to Nuttall, is "an understanding of how cultural forms move." Nuttal's reading of youth consumption leads her to conclude that $Y$ Culture's "commodity images...come to produce some of the most powerful reimaginings of race South Africa has known in some time."

To conclude: this book is useful for a quick overview of youth movements, on and off line. The anthology could be made stronger by focusing more specifically on how global youth appropriate and exploit both corporate and grass roots media/advertising techniques and tools to start movements and create culture. Or, as Lukose explains, "focus on the identification and tracking of agency and resistance among young people." For many youth, the digital divide prevents them from engaging in some of the movements presented here. However, as some of the authors have demonstrated, youth can imagine, create and self-actualize within the context of globalized consumer cultural forces. The power of social networking for social, political or other purposes is tremendous, and the imagination of our youth fully exploits these powers, once they can get their mouses clicking.

Vinita Srivastava is an assistant professor and the online stream director at the School of Journalism at Ryerson University. She runs Verse City, a multimedia youth empowerment project.

\section{For further exploration:}

Rwanda's Internet Revolution

Internet Evolution's Web Wide World takes us to Rwanda, a country torn apart by genocide, and now attempting a radical transformation from an agrarian society to a knowledge-based economy, via the Internet

http://www.internetevolution.com/document.asp?doc id=168518

A map of Africa indicating cell phone use and Internet users. Both indicate low usage in Rwanda and Ethiopia. Lowest users are recorded for Liberia.

http://whiteafrican.com/wp-content/uploads/2007/07/rwanda-internet.jpg

\section{COMMENTS:}

In order to proceed, please enter the code shown

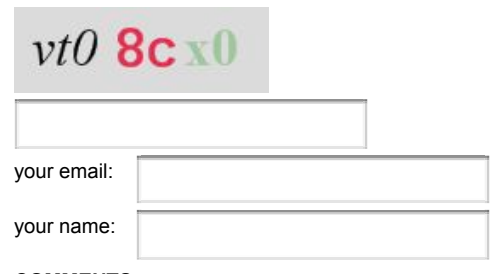

COMMENTS:

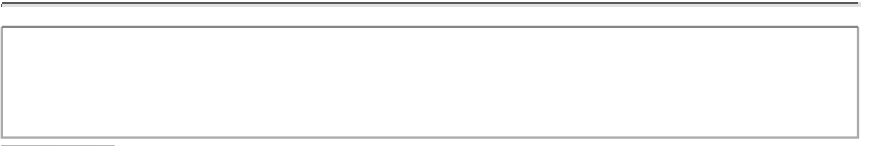

\section{SUBMIT}

Your e-mail is required, but will not be made public and will not be sold to any third party. Comments should promote a civil exchange of viewpoints, ideas and criticisms. Comments will not be moderated prior to appearing on the website, however Academic Matters reserves the right to remove posts that are:

Profane, lewd, hateful or otherwise offensive; defamatory or otherwise engaged in personal attacks; or unrelated to the content of the post.

Thank you for your cooperation in maintaining an open and engaging exchange of ideas on this website.

\section{OCUFA}


Privacy Policy Site Map Contact Us 